\title{
BIBECHANA
}

A Multidisciplinary Journal of Science, Technology and Mathematics

ISSN 2091-0762 (online)

Journal homepage: http://nepjol.info/index.php/BIBECHANA

\section{Assessment of physico-chemical parameters of surface water quality of Taudaha lake of Kathmandu and their comparison with other global published values}

\author{
Achut Ram Pradhananga ${ }^{1}$, Ramesh Kaji Shakya ${ }^{2}$, Pawan Raj Shakya ${ }^{{ }^{*}}$ \\ ${ }^{1}$ Department of Chemistry, Padma Kanya Multiple Campus, Tribhuvan University, Kathmandu \\ ${ }^{2}$ Department of Zoology, Padma Kanya Multiple Campus, Tribhuvan University, Kathmandu \\ *Corresponding Author Email: pawansh2003@yahoo.com \\ Article history: Received 10 Novemver; Accepted 24 November, 2012
}

\begin{abstract}
The aim of current study was to evaluate the status of Taudaha lake water with respect to different physico-chemical parameters $\left(\mathrm{pH}\right.$, electrical conductivity, dissolved oxygen, free $\mathrm{CO}_{2}$, total dissolved solids (TDS), total suspended solids (TSS), total solids (TS), total alkalinity, total hardness, chloride, nitrate, sulphate, phosphate, sodium, calcium, magnesium, lead, cadmium, copper and zinc) in monsoon season 2012. Results reveal that almost all the physico-chemical parameters including the elemental investigation of the lake water have values within the range of the maximum permissible levels for drinking water. The results were compared with WHO water quality guidelines as well as with literature values reported for global lake water.
\end{abstract}

Key words: Physico-chemical parameters; Taudaha lake; Surface water quality; WHO guideline values; trace and toxic elements.

\section{Introduction}

Lakes and surface water reservoirs are the planet's most important freshwater resources and provide innumerable benefits. They are used for domestic and irrigation purposes, and provide ecosystems for aquatic life especially fish, thereby functioning as a source of essential protein, and for significant elements of the world's biological diversity. They have important social and economic benefits as a result of tourism and recreation, and are culturally and aesthetically important for people throughout the world. They also play an equally important role in flood control [1]. However, the remarkable increase in population resulted in a considerable consumption of the water reserves world wide [2]. The quality of surface water is largely affected by natural processes (weathering and soil erosion) as well as anthropogenic inputs (municipal and industrial wastewater discharge). The anthropogenic discharges represent a constant polluting source, whereas surface runoff is a seasonal phenomenon, largely affected by climatic conditions $[3,4]$.

Among environmental pollutants, metals are of particular concern, due to their potential toxic effect and ability to bioaccumulation in aquatic ecosystems [5,6]. Therefore, it has public interest $[7,8]$. The serious environmental problems have been faced in developing as well as developed countries [9]. Dissolved constituents of water bodies are often determined as a major component for baseline limnological studies. The major ions $\mathrm{Ca}^{2+}, \mathrm{Mg}^{2+}, \mathrm{Na}^{+}, \mathrm{K}^{+}, \mathrm{Cl}^{-}, \mathrm{SO}_{4}{ }^{2-}, \mathrm{HCO}_{3}{ }^{-}$, and $\mathrm{CO}_{3}{ }^{2-}$ are essential constitute of water and 
responsible for ionic salinity as compared with other ions [10]. Contamination of aquatic ecosystems with heavy metals is a serious problem all over the world [11].

Water quality monitoring has a high priority for the determination of current conditions and long-term trends for effective management. The supply of safe water has a significant impact on the anticipation of water transmissible diseases [12]. The abundance of organic compounds, radionuclides, toxic chemicals, nitrites and nitrates in water may cause unfavorable effects on the human health especially cancer, other human body malfunctions and chronic illnesses [13]. Therefore, it is necessary to frequently monitor water quality, used for drinking purposes.

Taudaha, the only natural lake in Central Nepal at an altitude of $1350 \mathrm{~m}$ with $27^{\circ} 38.88^{\prime} \mathrm{N}$ latitude and $85^{\circ} 17.05^{\prime}$ E longitude is located approximately $10 \mathrm{~km}$ away from the center of Kathmandu [14]. The lake is situated here from the time immemorial holding historical significance of Kathmandu valley long before the settlement of human society. According to the legend, the lake was created by God Manjushree as a home for the king of serpents Karkotak and his wife who lost their home when the valley was drained. It is also believed that Karkotak resides to this day in the epicenter of the lake. At present, the mean depth of the lake is approximately $3 \mathrm{~m}$ and it covers an area of 4 hectare. It has eight corners with uneven in shape, nine inlets covering north-west agricultural fields and permanent outlet towards southwest. It is reported to have in average 0.12 million liters water inlets per day and outlet in average 0.27 million liters of water per day [14]. Because of the religious importance, townspeople come to the lake twice a year for paying homage to this sacred site. Presently, Karkotak Nagraja Nagrani Resident Restoration Society (KNNRRS) has been safe guarding the place that has now turned into recreation center for visitors and nature lovers as well as for ecological studies. Therefore, it has become necessary to monitor water quality to observe the pollution level of the surface water of the lake time to time. Several water analyses have been regularly conducted by different scientific groups across the country. The present work is an attempt to examine the water quality status of the lake with respect to different physico-chemical parameters in monsoon season.

\section{Material and Methods}

\section{Study site and sample collection}

Taudaha lake (Fig. 1) was selected for the study purpose because it holds the ancient history of Kathmandu valley. The sampling network was designed to cover a wide range of determinates of key sites, which reasonably represent the water quality of the lake system. Multiple samples for different analytical purposes were collected using separate PET bottles from 6 key sites of the same station in monsoon season. All water samples were delivered on the same day to laboratory and stored at $4^{\circ} \mathrm{C}$ until further processing and analysis.

\section{Analytical procedure}

Different physico-chemical parameters were determined using the following methods: the water temperature, $\mathrm{pH}$, electrical conductivity (EC), of each water sample were measured at the sampling points by a mercury thermometer, digital $\mathrm{pH}$ meter and EC meter, respectively. In laboratory, TDS, TSS and TS were determined by drying and weighing method. Measurement of DO was done by Winkler's Iodometric method while free $\mathrm{CO}_{2}$ by titrimetric method using standard $0.05 \mathrm{~N} \mathrm{NaOH}$ [15].

For anions and metal analysis, the duplicate aqueous samples of each site were filtered through Whatman filter paper No. 42 and the samples were divided into two parts. One part was used for analysis of anions and the remaining physico-chemical parameters, while second part treated with $1 \mathrm{~mL}$ of concentrated $\mathrm{HNO}_{3}$ for metal analysis. Total alkalinity was determined by acid titration using methyl-orange as endpoint while total hardness by complexometric titration method [15]. Chloride was measured by silver nitrate $\left(\mathrm{AgNO}_{3}\right)$ titration using potassium chromate $\left(\mathrm{K}_{2} \mathrm{CrO}_{4}\right)$ solution as an indicator and nitrate was measured by phenol disulphonic acid method [15]. Similarly, phosphate was determined by molybdate 
ascorbic acid method and sulphate was determined spectrophotometrically by barium sulfate turbidity method [16].

The acid-treated water samples were further diluted 20-time with ultrapure water for analyzing Na and $\mathrm{Ca}$, using flame photometry, while $\mathrm{Mg}$ was determined by the flame atomic absorption spectrometer (FAAS). For trace and toxic elements, the volume of water samples was reduced four-fold at $60^{\circ} \mathrm{C}$ on an electric hot plate. Zinc, copper, lead and cadmium were determined by Varian Model-AA240FS fast sequential atomic absorption spectrophotometer (AAS).

Reagents and solutions

All chemicals used were of analytical reagent grade or the highest purity available. Doubly distilled water was used throughout the study. Standard solutions of all the elements were prepared by dilution of certified standard solutions 1000 ppm, Fluka Kamica (Buchs SG and Switzerland) of corresponding metal ions. The quality of the analytical data was ensured through careful standardization and blank measurements. Descriptive statistics using simply mean and standard deviation was used for analysis of the results.

\section{Results and Discussion}

The physico-chemical parameters and elemental concentrations of water samples collected from 6 sampling sites of the Taudaha lake water are presented in Table 1, 2 and 3 respectively; the results are compared with the values of World Health recommended maximum permissible limits [17] and with other global published values on lakes in different continents.

The Taudaha lake water recorded $29{ }^{\circ} \mathrm{C}$ in average during the study period. The temperature is one of the important factors in aquatic environment since it regulates physicochemical as well as biological activities [18]. Mean $\mathrm{pH}$ value (8.9) of the lake water was found in the alkaline range (Table 1). The $\mathrm{pH}$ range (8.69.1) of the water samples were found above the upper limit defined by WHO guidelines of 6.5-8.5 [17]. High value of $\mathrm{pH}$ may result due to waste discharge, microbial decomposition of organic matter in the water body or may be attributed to sewage discharge by surrounding human population [19]. The ions $\left(\mathrm{Ca}^{2+}, \mathrm{Mg}^{2+}, \mathrm{Na}^{+}, \mathrm{K}^{+}, \mathrm{Cl}^{-}, \mathrm{SO}_{4}{ }^{2-}, \mathrm{HCO}_{3}{ }^{-}\right.$, and $\left.\mathrm{CO}_{3}{ }^{2-}\right)$ constitute the total ionic salinity in most fresh water as reported in literature [20]. Electrical conductivity is a measure of water capability to transmit electric current and also it is a tool to assess the purity of water. The EC values of the lake water were found to be lower as compared to the maximum permissible levels recommended by WHO (2004) guidelines for drinking water. The mean conductivity values of the lake water were lower than those reported in literature (Table 1) for other lakes [21-23, 31] except in the case of Tuskegee Lake, USA [30]. Mean TDS, TSS and TS values in the present study were found to be $124.5,621.4$ and $745.8 \mathrm{mg} / \mathrm{L}$ respectively. High levels of TDS, TSS and TS in water used for drinking purposes may lead to many diseases [33]. The WHO has established water quality standard of $500 \mathrm{mg} / \mathrm{l}$ to provide for palatability of drinking water [17]. Accordingly, the TDS value was found to be lower than the maximum permissible limit.

DO is of great importance to all living organisms. Besides, it is a very important parameter of water quality and an index of physical and biological process going on in water. It may be present in water due to direct diffusion from air and photosynthetic activity of autotrophs [19]. In the present study, the mean concentration of dissolved oxygen $(5.8 \mathrm{mg} / \mathrm{L})$ was found to be within the permissible level for drinking water (Table 1) [17]. This value was observed in monsoon season, which favours solubility of oxygen in water bodies [19]. Moitra and Bhattacharya [34] found maximum dissolved oxygen in winter season which they explained due to low temperature. The minimum dissolved oxygen was found in summer due to high temperature, and higher microbial demand of oxygen for decomposition of suspended organic matter $[35,36]$. Mean free $\mathrm{CO}_{2}$ was found to be $21.6 \mathrm{mg} / \mathrm{L}$ (Table 1), the value higher than the maximum permissible limit as defined by WHO guidelines [17]. Our results are in agreement with that reported by Chettry and Pal [37]. They observed positive and significant correlation with biological oxygen demand 
but inverse and significant correlation with total alkalinity and total hardness. However, minimum free carbon dioxide was reported during winter season [38].

Mean value of the total alkalinity of the lake water was found to be $111.7 \mathrm{mg} / \mathrm{L}$ (Table 1); the value being well below the maximum permissible limit according to WHO [17]. The value was also lower than that of Manchar Lake, Pakistan [21] but was higher than Tuskegee Lake, USA [30]. Das and Chand [39] also recorded low alkalinity during monsoon supporting our results, which might be due to dilution effect of rainfall. Total hardness is the total soluble magnesium and calcium salts present in the water expressed as its $\mathrm{CaCO}_{3}$ equivalent. The hardness of water increases in the polluted water by the deposition of such salts [19]. The total hardness in the Taudaha lake was found to be $106.3 \mathrm{mg} / \mathrm{L}$ (Table 1). This mean value lies within the range of the WHO recommended value [17]. Khan et al. [40] also found similar results in Triveni lake water of Amravati district, India during monsoon season. Similarly, Patralekh [41] recorded minimum quantity in rainy season stating due to more dilution of water. However, maximum total hardness in winter season might be due to low volume of water and slow current of water [42].

The concentrations of $\mathrm{Cl}^{-}, \mathrm{SO}_{4}{ }^{2-}$ and $\mathrm{PO}_{4}{ }^{3-}$ in Taudaha lake water did not exceed the WHO recommended values (Table 2). The value of $\mathrm{Cl}^{-}$was higher than that of Tuskegee Lake, USA [30] but significantly lower than Manchar lake, Pakistan [21]. According to Versari et al. [43], chloride concentrations higher than $200 \mathrm{mg} / \mathrm{L}$ are considered to be a risk for human health and may cause unpleasant taste of water. Munawar [44] has suggested that higher concentration of chloride in water is an index of pollution of animal origin and there is a direct relation between chloride concentration and pollution level. The concentration of $\mathrm{SO}_{4}{ }^{2-}$ in the lake water was significantly lower than those of the reported literature [21, $30]$ but the value was almost similar to Siberian Ponde [28]. On the contrary, the value of $\mathrm{PO}_{4}{ }^{3-}$ was found to be higher than Manchar lake, Pakistan [21] and Tuskegee lake, USA [30] but it was significantly lower than Kasumigaura lake, Japan [27]. The $\mathrm{NO}_{3}{ }^{-}$concentration in the lake was found to be $1.9 \mathrm{mg} / \mathrm{L}$.

It has been found that all the elemental investigation of the Taudaha lake water have lower values as compared to the maximum permissible levels of these elements in drinking water (Table 3). However, the concentration of $\mathrm{Ca}^{2+}$ was higher in the lake water sample as compared to $\mathrm{Mg}^{2+}$ and $\mathrm{Na}^{+}$. When compared with other global published values, the $\mathrm{Ca}^{2+}$ concentration was significantly lower than the value reported in the literature $[21,28]$ but was higher than those reported values in the literature [27, 30]. Similarly, the $\mathrm{Mg}^{2+}$ value in the lake water was significantly lower than Manchar Lake, Pakistan [21] and Latvian lakes [32] but was higher than Kasumigaura lake, Japan [27] and Tuskegee lake, USA [30]. Likewise, the $\mathrm{Na}^{+}$ value in the lake water was significantly lower than the reported values in the literature $[21,22,27,32]$ but higher than the value of Tuskegee lake, USA [30]. It has been reported that high consumption of salts, particularly $\mathrm{NaCl}$, may be crucial for the development of hypertension and increases the risk for stroke, left ventricular hypertrophy, osteoporosis, renal stones and asthma [45].

The concentration of toxic elements $\mathrm{Cd}, \mathrm{Cu}, \mathrm{Pb}$ and $\mathrm{Zn}$ detected in the lake water were found to be multifold lower than the maximum permissible limits of these elements in drinking water (Table 3). The level of $\mathrm{Cd}$ in the lake water was significantly lower than Manchar lake (Pakistan) [21], Lake Nakuru (Kenya) [22] and Nacharam Lake (India) [29] while higher than the other lakes [23, 24, 26, 27, 28, 30-32] (Table 3). It has been reported that the elevated concentrations of $\mathrm{Cd}$ can cause nausea, vomiting, salivation and renal failure as well as kidney, liver and blood damages [46]. The concentration of $\mathrm{Pb}$ in the understudy lake water was higher than other 8 lakes water samples [23, 24, 26, 27, 29-32] but significantly lower than those reported in the literature $[21,28]$. The adverse health effects of lead consist of various cancers, adverse reproductive outcomes, cardiovascular and neurological diseases [47]. $\mathrm{Cu}$ and Zn showed almost similar behaviour and their concentrations in the lake water were found to be significantly lower than the maximum permissible levels (Table 3). Besides, they were also found to be lower than the reported values of the literature [21, 22, 25] but higher than other lake water samples [3032]. Both the metals are essential nutrients for plants and animals, occurring naturally in environment. In natural waters, $\mathrm{Cu}$ and $\mathrm{Zn}$ are largely bound to dissolved organic compounds. $\mathrm{Cu}$ is excreted in animal 
Achut Ram Pradhananga et al.I BIBECHANA 9 (2013) 141-150: BMHSS, p.145 (Online Publication: Nov., 2012)

Table 1: Physico-chemical parameters of Taudaha lake water and comparison with other global published values (mean \pm S.D., $n=6$ ).

\begin{tabular}{|c|c|c|c|c|c|c|c|c|c|}
\hline Study Area & pH & $\begin{array}{c}\text { Conductivity } \\
(\mu \mathrm{S} / \mathrm{cm})\end{array}$ & $\begin{array}{c}\text { TDS } \\
(\mathrm{mg} / \mathrm{L})\end{array}$ & $\begin{array}{c}\text { TSS } \\
(\mathrm{mg} / \mathrm{L})\end{array}$ & $\begin{array}{c}\mathrm{TS} \\
(\mathrm{mg} / \mathrm{L})\end{array}$ & $\begin{array}{c}\text { DO } \\
(\mathrm{mg} / \mathrm{L})\end{array}$ & $\begin{array}{c}\text { Free } \\
\mathrm{CO}_{2}(\mathrm{mg} / \mathrm{L})\end{array}$ & $\begin{array}{c}\text { T. } \\
\text { Alkalinity } \\
(\mathrm{mg} \\
\left.\mathrm{CaCO}_{3} / \mathrm{L}\right)\end{array}$ & $\begin{array}{c}\mathrm{T} . \\
\text { Hardness } \\
(\mathrm{mg} \\
\left.\mathrm{CaCO}_{3} / \mathrm{L}\right)\end{array}$ \\
\hline $\begin{array}{c}\text { WHO Standard } \\
{[17]}\end{array}$ & $6.5-8.5$ & $800-1000$ & 500 & - & - & $4-6$ & 6 & 200 & $80-120$ \\
\hline $\begin{array}{l}\text { Taudah Lake, } \\
\text { Nepal (*P.S.) }\end{array}$ & $8.5 \pm 0.2$ & $231.7 \pm 16.0$ & $124.5 \pm 19.2$ & $621.4 \pm 23.3$ & $745.8 \pm 69.2$ & $5.8 \pm 0.9$ & $21.6 \pm 5.3$ & $111.7 \pm 6.1$ & $106.3 \pm 4.6$ \\
\hline $\begin{array}{l}\text { Manchar Lake, } \\
\text { Pakistan [21] }\end{array}$ & $8.4 \pm 0.2$ & $5243.6 \pm 178.6$ & - & - & - & - & - & $157.0 \pm 40.3$ & - \\
\hline $\begin{array}{c}\text { Lake Nakuru, } \\
\text { Kenya [22] }\end{array}$ & $10.3 \pm 0.3$ & $27,500 \pm 276$ & - & - & - & - & - & - & - \\
\hline $\begin{array}{l}\text { Mc Farlane, } \\
\text { Canada [23] }\end{array}$ & $8.2 \pm 0.0$ & $370 \pm 0.6$ & - & - & - & - & - & - & - \\
\hline $\begin{array}{l}\text { Lake Balaton, } \\
\text { Hungary [24] }\end{array}$ & - & - & - & - & - & - & - & - & - \\
\hline $\begin{array}{l}\text { Hazar Lake, } \\
\text { Turkey [25] }\end{array}$ & - & - & - & - & - & - & - & - & - \\
\hline $\begin{array}{l}\text { Lake Doirani, } \\
\text { Greece [26] }\end{array}$ & - & - & - & - & - & - & - & - & - \\
\hline $\begin{array}{c}\text { Lake } \\
\text { Kasumigaura, } \\
\text { Japan [27] } \\
\end{array}$ & $8.0 \pm 0.1$ & - & - & - & - & - & - & - & - \\
\hline $\begin{array}{c}\text { Siberian Ponde } \\
{[28]}\end{array}$ & $7.7-9.5$ & - & - & - & - & - & - & - & - \\
\hline $\begin{array}{c}\text { Nacharam Lake, } \\
\text { India [29] }\end{array}$ & - & - & - & - & - & - & - & - & - \\
\hline $\begin{array}{c}\text { Tuskegee Lake, } \\
\text { USA [30] }\end{array}$ & $7.4 \pm 0.2$ & $82.5 \pm 0.7$ & - & - & - & - & - & $29.7 \pm 1.3$ & - \\
\hline $\begin{array}{c}\text { Lapland, } \\
\text { Finland [31] }\end{array}$ & 5.7 & 1300 & - & - & - & - & - & - & - \\
\hline $\begin{array}{c}\text { Latvian Lakes } \\
{[32]}\end{array}$ & $6.5-8.1$ & - & - & - & - & - & - & - & - \\
\hline $\begin{array}{c}* \text { P.S. }- \\
\text { Present study }\end{array}$ & & & & & & & & & \\
\hline
\end{tabular}


Achut Ram Pradhananga et al./ BIBECHANA 9 (2013) 141-150: BMHSS, p.146 (Online Publication: Nov., 2012)

Table 2: Physico-chemical parameters of Taudaha lake water and comparison with other global published values (mean \pm S.D., $n=6$ ).

\begin{tabular}{|c|c|c|c|c|}
\hline Study Area & $\begin{array}{c}\text { Chloride } \\
\text { (mg/L) }\end{array}$ & $\begin{array}{l}\text { Nitrate } \\
(\mathrm{mg} / \mathrm{L})\end{array}$ & $\begin{array}{l}\text { Sulphate } \\
\text { (mg/L) }\end{array}$ & $\begin{array}{c}\text { Phosphate } \\
\text { (mg/L) }\end{array}$ \\
\hline WHO Standard [17] & 250 & - & 250 & 0.8 \\
\hline Taudah Lake, Nepal (*P.S.) & $18.6 \pm 2.1$ & $1.9 \pm 0.2$ & $1.5 \pm 0.4$ & $0.6 \pm 0.1$ \\
\hline Manchar Lake, Pakistan [21] & $1260 \pm 251$ & - & $163.8 \pm 13.4$ & $0.5 \pm 0.2$ \\
\hline Lake Nakuru, Kenya [22] & - & - & - & - \\
\hline Mc Farlane, Canada [23] & - & - & - & - \\
\hline LakeBalaton, Hungary [24] & - & - & - & - \\
\hline Hazar Lake, Turkey [25] & - & - & - & - \\
\hline Lake Doirani, Greece [26] & - & - & - & - \\
\hline Lake Kasumigaura, Japan [27] & - & - & - & 8.0 \\
\hline Siberian Ponde [28] & - & - & 1.3 & - \\
\hline Nacharam Lake, India [29] & - & - & - & - \\
\hline Tuskegee Lake, USA [30] & $9.3 \pm 0.6$ & - & $8.8 \pm 2.1$ & $0.07 \pm 0.04$ \\
\hline Lakes in Lapland, Finland [31] & - & - & - & - \\
\hline Latvian Lakes [32] & - & - & - & - \\
\hline *P.S. - Present Study & & & & \\
\hline
\end{tabular}


Achut Ram Pradhananga et al./ BIBECHANA 9 (2013) 141-150: BMHSS, p.147 (Online Publication: Nov., 2012)

Table 3: Physico-chemical parameters of Taudaha lake water and comparison with other global published values (mean \pm S.D., $n=6$ ).

\begin{tabular}{|c|c|c|c|c|c|c|c|}
\hline Study Area & $\begin{array}{c}\mathrm{Ca} \\
(\mathrm{mg} / \mathrm{L})\end{array}$ & $\begin{array}{c}\mathrm{Mg} \\
(\mathrm{mg} / \mathrm{L})\end{array}$ & $\begin{array}{c}\mathrm{Na} \\
(\mathrm{mg} / \mathrm{L})\end{array}$ & $\begin{array}{c}\text { Cd } \\
(\mu \mathrm{g} / \mathrm{L})\end{array}$ & $\begin{array}{c}\mathrm{Cu} \\
(\mu \mathrm{g} / \mathrm{L})\end{array}$ & $\begin{array}{c}\mathrm{Pb} \\
(\mu \mathrm{g} / \mathrm{L})\end{array}$ & $\begin{array}{c}\mathrm{Zn} \\
(\mu \mathrm{g} / \mathrm{L})\end{array}$ \\
\hline WHO Standard [17] & 100 & 50 & 200 & 3 & 2000 & 10 & 3000 \\
\hline Taudah Lake, Nepal (*P.S.) & $36.2 \pm 3.5$ & $7.8 \pm 1.9$ & $6.4 \pm 0.7$ & $1.0 \pm 0.3$ & $7.8 \pm 5.7$ & $5.3 \pm 0.2$ & $10.0 \pm 1.0$ \\
\hline Manchar Lake, Pakistan [21] & $219.9 \pm 45.9$ & $167.1 \pm 53.1$ & $433.1 \pm 93.0$ & $5.0 \pm 1.4$ & $19.1 \pm 4.3$ & $82.2 \pm 18.6$ & $720.2 \pm 146$ \\
\hline Lake Nakuru, Kenya [22] & - & - & $281.0 \pm 22.0$ & $43.0 \pm 1.4$ & $100.0 \pm 9.7$ & - & $138 \pm 10.6$ \\
\hline Mc Farlane, Canada [23] & - & - & - & $0.03 \pm 0.001$ & $11.0 \pm 23.0$ & $0.14 \pm 0.03$ & $2.4 \pm 0.4$ \\
\hline Lake Balaton, Hungary [24] & - & - & - & $1.5 \times 10^{-3}$ & - & $0.04-0.33$ & $0.2-1.9$ \\
\hline Hazar Lake, Turkey [25] & - & - & - & - & 18.0 & - & $38-71$ \\
\hline Lake Doirani, Greece [26] & - & - & - & $0.1-0.4$ & $1.0-13.0$ & $1.0-1.6$ & $6.0-66.0$ \\
\hline Lake Kasumigaura, Japan [27] & 14.8 & 4.9 & 11.5 & 0.02 & 2.9 & 0.4 & 3.8 \\
\hline Siberian Ponde [28] & $38.6 \pm 2.4$ & - & - & $<1$ & $2.3 \pm 0.4$ & $8.8 \pm 3.6$ & - \\
\hline Nacharam Lake, India [29] & - & - & - & $8.9 \pm 3.5$ & - & $0.9-5.0$ & $21-142$ \\
\hline Tuskegee Lake, USA [30] & $6.8 \pm 1.9$ & $2.4 \pm 0.9$ & $3.3 \pm 0.2$ & $0.001 \pm 0.005$ & $0.5 \pm 0.9$ & $0.1 \pm 0.3$ & $5.5 \pm 4.4$ \\
\hline Lapland, Finland [31] & - & - & - & 0.02 & - & $0.5-1.2$ & $1.9-3.6$ \\
\hline Latvian Lakes [32] & $1.5-74.1$ & $15.5 \pm 0.4$ & $39.0 \pm 2.2$ & $0.01-0.08$ & $0.3 \pm 0.1$ & $2.3 \pm 0.2$ & $0.02 \pm 0.02$ \\
\hline * P.S. - Present study & & & & & & & \\
\hline
\end{tabular}


waste, which can contaminate water, and may impair human health. Zn may also increase the acidity of water [47]. Although humans can handle proportionally large concentration of zinc, too much zinc can still cause eminent health problems, such as stomach cramps, skin irritations, vomiting, nausea and anemia [48].

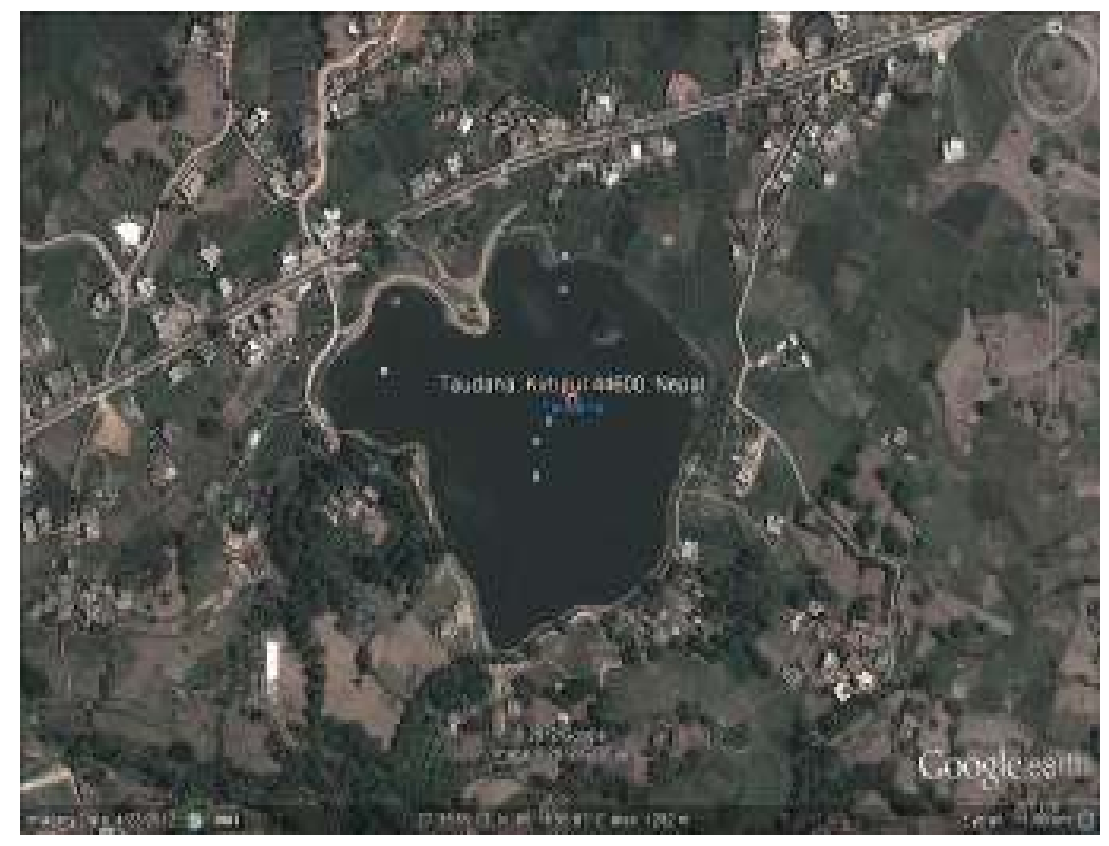

Fig. 1: Taudaha Lake (Study area; source: Google Earth)

\section{Conclusion}

As might be evident from the present study that the Taudaha lake possesses better water quality status under the study period since all the physico-chemical analyzes indicate the values within the maximum permissible limits for drinking water as recommended by WHO. Besides, the surface water quality of the lake is also found to be in better condition than many of the reported global lake water. Nevertheless, the physico-chemical parameters undertaken for the present study may have either positive or negative correlation with one another. Further investigation on seasonal variation in the water quality parameters is therefore required to arrive at the specified conclusion. Since the lake is of historic importance, it may be suggested for interventions on any kind of anthropogenic activities which bear responsibilities for the lake water quality deterioration. It may be expected that the outcomes of the present investigation may furnish useful information for future planning in using the lake water for drinking purpose. 


\section{Acknowledgements}

The authors are very thankful to Department of Science, Padmakanya Multiple Campus, Tribhuvan University for providing the lab facilities. Aastha Scientific Research Service Pvt. Ltd., Dillibazar, Kathmandu is also greatly acknowledged for part of analytical services.

\section{References}

[1] Y.J. An, D.H. Kampbell and G.W. Sewell, Environ. Pollut., 118 (2002) 331.

[2] K.C. Ho, Y.L. Chow and J.T.S. Yau, Chemosphere, 52 (2003) 1441.

[3] K.P. Singh, A. Malik, D. Mohan and S. Sinha, Water Res., 38 (2004) 3980.

[4] M. Vega, R. Pardo, E. Barrado, D. Leban, Water Res., 32 (1998), 3581.

[5] G.G. Miller, L.I. Sweet, J. V. Adams, G.M. Omann, D. Passino-Reader and P. G. Meter, Fish Shellfish Immun., 13 (2002) 11.

[6] P. Censi, S.E. Spoto, F. Saiano, M. Sprovieri, S. Mazzola and G. Nardone, Chemosphere, 64 (2006) 1167.

[7] R.J. Gibbs, Water chemistry of the Amazon River, Geochim. Cosmochim. Acta, 36 (1972) 1061.

[8] G.J. Niemi, P. DeVore, N. Detenbeck, D. Taylor, A. Lima, J. Pastor, J.D. Yount and R.J. Naiman, Environmental Management 14 (1990) 571.

[9] J.J. Listori and World-wide Bank Environmental Health Components for Water Supply, Sanitation and Urban Projects. World wide Bank, Washington, DC. (1990).

[10] R.G. Wetzel, and G.E. Likens. Limnological Analyses. 2nd Ed., Springer-Verlag, New York (1991).

[11] A. Wagner and J. Boman, Spectrochim. Acta Part B, 58 (2003) 2215.

[12] D.E. Lerda and C.H. Prosperi, Water Res., 30 (1996) 819.

[13] A. Ikem, S. Odueyungbo, N.O. Egiebor and K. Nyavor, The Science of the Total Environment, 285 (2002) 165.

[14] www.Taudah-paper/taudaha-lake-of-kirtipur.html

[15] R.K. Trivedy and P.K. Goel, Chemical and biological methods for water pollution studies. Environmental Publications, Karad, India (1986).

[16] L.S. Clesceri, A.E. Greenberg and A.D. Eaton, (Eds.), Standard Methods for the Examination of Water and Wastewater, 20th ed. American Public Heath Association (APHA), American Water Works Association (AWWA) and Water Environment Federation (WEF), Washington, DC. (1998).

[17] WHO, Guidelines for drinking-water quality, 3rd ed. WHO, Geneva, Switzerland, (2004).

[18] A. Kumar, H.P. Gupta and D.K. Singh, J. Ecol., 23 (1996) 82.

[19] S.G. Patil, S.G. Chonde, A.S. Jadhav and P.D. Raut, Research Journal of Recent Sciences, 1 (2012) 56.

[20] G.M. Zinabu, L.J. Chapman and C.A. Chapman, Limnologica, 32 (2002) 21.

[21] M.B. Arain, T.G. Kazi, M.K. Jamali, H.I. Afridi, J.A. Baig, N. Jalbani and A.Q. Shah, Pak. J. Anal. Environ. Chem., 9 (2008) 101.

[22] E.Z. Ochieng, J.O. Lalah and S.O. Wandig, Bull. Environ. Contam. Toxicol., 79 (2007) 570.

[23] M. Shuhaimi-Othman, D. Pascoe, U. Borgmann Andw and P. Norwood, Environ. Monit. Assess., 117 (2006) 27.

[24] H.L. Nguyen, M. Leermakers, S. Kurunczi, L. Bozo and W. Baeyens, Science of the Total Environment, 340 (2005) 231.

[25] H. Ozmen, F. Kulahci, A.C. Ukurovali and M. Dogru, Chemosphere, 55 (2004) 401.

[26] A. Anthemidis, G. Zachariadis, D. Voutsa, A. Kouras and C. Samara, Variation of heavy metals and other toxic element concentrations in surface water of Macedonia, In: Proceedings of $1^{\text {st }}$ Environmental Conference of Macedonia, Thessaloniki, Greece, (2002) 104.

[27] M. Alam, A. Tanaka, F. Stagnitti, G. Allinson and T. Maekawa, Ecotoxicology and Environmental Safety, 48 (2001) 107.

[28] M.I. Gladyshev, I.V. Gribovskaya, A.V. Moskvicheva, E.Y. Muchkina, S.M. Chuprov and E.A. Ivanova, Arch. Environ. Contam. Toxicol., 41(2001) 157. 
[29] P.K. Govil, G.L.N. Reddy and T. Gnaneswara Rao, J. Environ. Health, 61(1999) 23.

[30] A. Ikem, N.O. Egiebor and K. Nyavor, Water, Air, Soil, .Pollut., 149 (2003) 51.

[31] J. Mannio, O. Jarvinen, R. Tuominen and M. Verta, Sci. Tot. Environ., 160 (1995) 433.

[32] M. Klavins, V.Rodinovs and G. Vereskuns Bull. Environ. Contam. Toxicol., 60 (1998) 538.

[33] B.C. Sabata and M.P. Nayar, River pollution in India: A case study of Ganga river, (1995) 33.

[34] S.K. Moitra and B.K. Bhattacharya, Ichthyol. 4 (1965) 8.

[35] B.N. Bhowmick and A.S. Singh, 1985. Indian J. Ecol., 12 (1985) 141.

[36] J.P. Palharya and S. Malviya, Pollution of the Narmada at Hoshangabad in Madhya Pradesh and suggested measures for control. In Ecology and pollution of Indian rivers (Ed. R.K. Trivedy), Ashish Publishing House, New Delhi. (1988) 55.

[37] D. Thapa Chhetry and J. Pal, Our Nature, 9 (2011) 156.

[38] K.K. Pandey and M.S. Lal, J. Freshwater Biol. 7 (1995) 7.

[39] S.K. Das and B.K. Chand, India. J. Ecotoxical Environ. Monit., 13 (2003) 97.

[40] R.M. Khan, M.J. Jadhav and I.R. Ustad, Bioscience Discovery, 3 (2012) 64.

[41] L.N. Patralekh, J. Freshwater Biol. 6 (1994) 115.

[42] A.P. Mishra, B.K. Bora and M. Sharma, J. Freshwater Biol. 11 (1999) 1.

[43] A.Versari, G.P. Parpinello and S. Galassi, J. Food Compos. Anal., 15 (2002) 251.

[44] M. Munawar, Hydrobiol. 35 (1970) 127.

[45] M.F. McCarthy, Med Hypotheses, 63 (2004) 138.

[46] G. M. Gadd, New Phytol., 124 (1993) 25.

[47] G. M. Gadd and A. J. Griffiths, Microb. Ecol. 4, (1978) 303.

[48] T.C. Hutchinson and P.M. Stokes. Am. Soc. Test. Mater. Spec. Tech. Pub. 573 (1975) 320. 